potato crop it is unlikely to be of much importance as a field transmitter of virus diseases in most seasons and most localities. On the other hand, it has been recorded on Hordeum, Avena, and Trifolium pratense under field conditions, and this fact should be taken into account by workers who are attempting to maintain healthy stocks of potatoes in the field by isolating them in cereal crops or by intervening meadow land. Theobald found it in great abundance out of doors in May, and quotes Laing as saying that the species breeds quite readily outdoor in mid-summer. Under glasshouse conditions it feeds voraciously on potatowhether sprouts, stem or leaves, and, with us, it has proved more prolific than either $M$. persicce or Macrosiphum gei on potato.

Those facts and the ease with which the apterous viviparous female can be distinguished from other potato-feeding aphides make it a valuable species with which to work on virus transmission. Most of my work with aphis vectors has been carried out during the winter and spring months, and it is conceivable that summer generations of some species of aphides might vary in the efficiency with which they will transmit virus diseases. May not this be a partial explanation of the negative results recorded by some workers when using species other than $M$. persica? ?

University College of North Wales, T. WHITEHEAD. Bangor, June 16.

\section{A Relation between the Continuous and the} Many-Lined Spectra of Hydrogen.

RECENT investigations on the continuous and the many-lined spectra of hydrogen seem to show that there is some relation between the origin of the continuous spectrum and the electronic states of the term systems of the spectra of the hydrogen molecule. We have often observed in our experiments that although the intensity of the continuous spectrum seems quite independent of the intensity of the atomic lines, certain band groups of the many-lined spectrum in the whole region of the visible are often strong when the continuous spectrum is intense. In an ordinary discharge tube, for example, this continuous spectrum is produced with strong intensity at high pressure ( $5.8 \mathrm{~cm}$. of mercury), and is accompanied by the band groups of the triplet system of the hydrogen molecule in greater intensity than the other many-lined spectrum. According to our observations, most of them are classified as the transitions $2^{3} \Sigma-3^{3} \mathrm{II}$, (Fulcher bands) and $2^{3 \Sigma}-4^{3} \Pi$.

According to the interpretation of J. G. Winans and R. C. G. Stueckelberg (Proc. Nat. Acad. Sci., 14, 867 ; 1928 ), this continuous spectrum originates in the transition from any one of the excited triplet levels to the unquantised ground state $(13 \Sigma)$ of this system. Thus the above experimental fact suggests one relation between the continuous spectrum and the many-lined spectrum of hydrogen and seems to favour the view of Winans and Stueckelberg. After further experiments the results will be published elsewhere in detail.

The Physical Institute,

Imperial University, Sendai, Japan, May 3.

\section{Siliceous Shells of Protozoa.}

IT is of course well known that some Protozoa (as Radiolaria and Heliozoa) have the hard parts siliceous, while others (as Foraminifera) have them calcareous. Sponges show analogous groups. In $1911,{ }^{1}$ when discussing the freshwater genus Quadrulella (Rhizopoda), I remarked : "In his recently published (1911) paper on the Rhizopods of the British Antarctic Expedition, Penard calls attention to the curious fact that while the square plates of $Q$. symmetrica are siliceous, those of $Q$. irregularis (Archer) are calcareous, and will dissolve in hot concentrated sulphuric acid. He therefore inclines to agree with Awerinzew that the two animals are really generically distinct, and represent a case of convergent evolution." "There has just been published a very interesting paper by Heron-Allen and Earland ${ }^{2}$ in which they describe a new genus (Miliammina) of Foraminifera with a siliceous test, represented by five species in the Antarctic. But, in 1914, Chapman dealt with one of these species, calling it a new variety arenacea of the northern Miliolina oblonga (Montagu). The new form is said to be a siliceous 'isomorph' of the porcellanous $M$. oblonga. The question naturally arises, whether in such cases we do have 'convergent evolution', as I postulated in 1911, or divergent evolution, the form of the shell being ancestral, the material of it changed. HeronAllen and Earland are a little ambiguous about the type species of their new genus. I now formally designate as such Miliammina arenacea (Chapman), which they, for no apparent reason, call $M$. oblonga (Chapman).

University of Colorado,

Boulder, Colorado, May 17.

1 University of Colorado, 8, No. 4, p. 240.

2 Jour. Royal Microscopical Society, March 1930, p. 38 et seq.

\section{Slug or Horned Viper?}

THe earliest example of the animal which is shown in Prof. T. D. A. Cockerell's letter in NATURE of May 17 proves that it is a snake and not a slug.

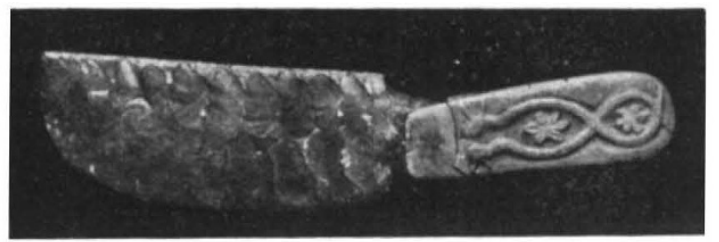

Fig. 1.

The chronological evidence is of importance, for Prof. Cockerell's example dates only to about 1400 B.C., while the ivory carving is predynastic, that is, before 3000 B.C.

University College,

Gower Street, London, W.C.1.

The Diffraction of $\mathrm{X}$-rays by Vitreous Solids and its Bearing on their Constitution.

I was interested to see the statement, by Messrs. J. T. Randall, H. P. Rooksby, and B. S. Cooper on the above subject in NATURE of Mar. 22, p. 458, that silica glass corresponds to either cristobalite or tridymite crystallites of average size $1.5-2 \cdot 0 \times 10^{-7} \mathrm{~cm}$. This confirms the theory of the formation of glass I published in the Transactions of the Society of Glass Technology in 1919 (vol. 3, p. 282). I pointed out then that glass is not a super cooled liquid, such as phenol, which becomes solid on the addition of a small crystal of that substance, but is a solid colloid consisting of amicroscopic crystals, the formation of which is due to the high viscosity and degree of aggregation of the components in the fused state.

The Science Museum,

S. C. Bradford.

South Kensington,

London, S.W.7, May 15. 